\title{
AN ANALYSIS OF BUSINESS PERFORMANCE ATTRIBUTABLE TO SUPPLY CHAIN MANAGEMENT IMPLEMENTATION
}

\author{
Güzin CÍRAVOĞLU $U^{1}$, Ayse AKYOL ${ }^{2}$ \\ ${ }^{1}$ Trakya Üniversitesi, Havsa Meslek Yüksek Okulu, Öğretim Görevlisi \\ ${ }^{2}$ Trakya Üniversitesi, İ.I.B.F., Issletme, Doçent Dr.
}

\section{AN ANALYSIS OF BUSINESS PERFORMANCE ATTRIBUTABLE TO SUPPLY CHAIN MANAGEMENT IMPLEMENTATION}

\begin{abstract}
The objective of this research is to examine empirically the implementation of supply chain management in Turkish Drug / Pharmaceuticals businesses in Thrace Region and to investigate variations in business performance which may be related to supply chain management. First, an exploratory phase was conducted and second, Lee et al. [1] supply chain management construct was used to test the hypothesis. The sample for both stages was drawn from a listing of the member companies of the Turkish Pharmaceuticals Association. Data generation was achieved through mail questionnaires. Results were analyzed using SPSS. The results of this research draw conclusions from an empirical investigation showing that the proposed relationship between supply chain management and business performance does exist, and in the case of Turkish Drug businesses, improving a supply chain management level is a contributor to the business performance.
\end{abstract}

Keywords: Supply Chain Management, Performance, Pharmaceuticals

\section{INTRODUCTION}

We have entered a new era in understanding the dynamics of competitive advantage and the role played by procurement. We no longer talk about suppliers and customers as though they are managed in isolation, each treated as an independent entity. More and more, we are witnessing a transformation in which suppliers and customers are inextricably linked throughout the entire sequence of events that bring raw material from its source of supply, through different value-adding activities to the ultimate customer. Success is no longer measured by a single transaction; competition is, in many instances, evaluated as a network of co-operating companies competing with other firms along the entire supply chain [2].

Quinn (1993) stated that, world class companies are now accelerating their efforts to align processes and information flows throughout their entire value-added network to meet the rising expectations of a demanding marketplace. We hear from enlightened managers

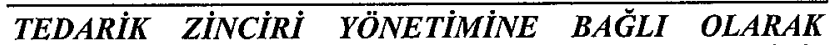
DEĞİSEBILECEK ŞIRKET PERFORMANSININ ANALIZİ

Özet: Bu araştırmanın amacı,Trakya bölgesindeki ilaç sektöründe Tedarik Zinciri Yönetimi uygulamalartntn incelenmesi ve bu uygulamalarin şirket performansı üzerine olan etkilerinin ampirik olarak analiz edilmesidir. Ilk olarak keşfedici araştırma uygulanmuş, daha sonra hipotezleri test etmek için Lee vd. [1] tarafindan geliştirilen ölçek kullantmuştır. Her iki aşama için ana kütle ve örnek kütle "Eczacilar Odast"na üyeler arasından seçilmiştir. Veriler posta yoluyla anket yöntemi kullantlarak elde edilmiştir. Veriler SPSS kullantarak analiz edilmiştir. Araştırma sonuçlarına göre tedarik zinciri yönetimi uygulamaları ve şirket performansı arasında ilişki vardır ve ilaç sektörü̈nde tedarik zinciri yönetimi uygulamalart düzeyi, şirket performansina etki etmektedir.

Anahtar Kelimeler: Tedarik Zinciri Yönetimi, Performans, Ilaç Sektörü

worldwide that success is now measured by cost, speed, innovation and customer satisfaction. This new view of the world is echoed by Porter (1985), who advocates that the coordination of complex global networks of company activities is becoming a prime source of competitive advantage. The secret is to achieve breakthrough changes and improvements so that the enterprise of members of the value-added network is shared throughout the system. Now we see that fill-the-order component makers are being asked to participate in the customer satisfaction delivery process as design partners, risk-sharers and engines of greater efficiency. These attempts at integrating this value-added and competitive advantage are referred to as Supply Chain Management (SCM) [3].

Effective SCM has become a formidable weapon in the marketing strategy arsenal. Having the right product available in the right quantities at the right time has become a critical ingredient for marketing success. Buyers and suppliers (retailers and distributors) are recognizing that the nature of their interactions has an important influence on this important activity. They 
realized that by working together, they are better able to serve the end customer (the consumer) and at the same time enhance their own profitability. This collaborative strategy enhances their position for maintaining and improving their competitive advantage [4].

Recent developments in information and communication technology (ICT), coupled with the collapse of barriers to market entry and other trading barriers has meant that managing the supply chain in the twenty-first century presents a rather different proposition for the manager. Operating in the global economy is no longer restricted to large international organizations, even the smallest of businesses now has the potential to trade in the global economy by virtue of the ICT developments. In addition to these developments, assessments have been made that the rate of innovation, in terms of product/service outputs, the production/delivery processes and consequently consumer preferences/markets will continue to increase more rapidly [5].

\section{Definition of Supply Chain Management}

SCM encompasses the planning and management of all activities involved in sourcing and procurement, conversation, and all Logistic Management activities. Importantly, it also includes coordination and collaboration with channel partners, which can be suppliers, intermediaries, third-party services providers, and customers. In essence, SCM integrates supply and demand management within and across companies [6]. Analytically, a typical supply chain is a network of materials, information and services processing links with the characteristics of supply transformation, and demand. The term SCM has been used to explain the planning and control of materials and information flows as well as the logistics activities not only internally within a company but also externally between companies [7].

SCM is the strategic and systematic coordination of firm functions and plans which include all firms in the chain in order to increase long term performance of supply chain and all firms in the chain. Therefore, Supply Chain Management is integration of business processes of products, services and information which add value to customers from first supplier to consumer [8].

Lummus et al. [9] conclude that Supply Chain Management (SCM) includes the logistics flows, the customer order management, the production processes, and the information flows necessary to monitor all the activities at the supply chain nodes. Mentzer et al. [10] conclude that SCM is the management of close inter-firm relationships, and that understanding partnering is important in developing successful retail supply chain relationships. Chandra and Kumar [11], mention that many firms have moved aggressively to improve SCM to balance customers' demands with the need for profitable growth. These efforts have been focused mainly on flexible organizations, organizational relationships, total supply chain coordination, improved inter - and intra enterprise communication, outsourcing of non-core competencies, built-to-order manufacturing strategy, inventory management, and cost control [11]. Lambert et al. [12], state that the objective of SCM is to maximize competitiveness and profitability for the company as well as the whole supply chain network, including the endcustomer. Carter et al. [13] define SCM as a coordinated approach for managing the flow of goods from suppliers to ultimate consumers, and that the goal is to meet customer service objectives while minimizing inventory and related costs. Another definition of SCM, according to Ellram et al. [14], is that it is an approach whereby the entire network, from the supplier through to the ultimate customer, is analyzed and managed in order to achieve the best outcome for the whole system. Turner [15] states that SCM is a technique that looks at all the links in the chain from raw materials suppliers, through the various levels of manufacturing, to warehousing and distribution to the final customer. Christopher [16] describes that the supply chain is the network of organizations that are involved, through upstream and downstream linkages, in the different processes and activities that each produce value in the form of products and services in the hands of the ultimate consumer. Towill et al. [17] state that the supply chain is a system, the constituent parts of which include material suppliers, production facilities, distribution services, and customers, all linked together via the forward flow of materials and the feedback flow of information. Cavinato [18] writes that the supply chain consists of actively managed channels of procurement and distribution and that is made up of a group of firms that adds value along the product flow from original raw materials to final customer. It concentrates on relational factors rather than transactional ones.

\section{Components of Supply Chain Management}

The first component of SCM is the utilization of information technology. Examples of the information technology are computer-to-computer communication, electronic data interchange (EDI), POS data communication, and bar-coding. Electronic links between suppliers and carriers or customers are critical for information sharing. Technologies at each stage of the supply chain should be compatible with their partners' to better streamline the information. Types of information fed into this electronic links are data on sales, usage, product changes, promotions, discontinuations, and product and process [1].

Utility expectation is the second component. The most immediate benefits that business can expect from SCM are lowered inventory risk and costs, along with reductions in warehousing, distribution, and transportation costs. Over time firms will also experience 
sustainable cost savings through increased productivity and streamlined business processes in procurement and purchasing, order fulfilment, accounts receivable and payable, and exception management. More subtle benefits can include accelerated product delivery times, more efficient product development efforts, and lower product manufacturing costs. In the long term, the most significant benefits to business with advanced SCM capabilities will be dramatically improved customer responsiveness, increased flexibility for changing market conditions, improved customer services and satisfaction, increased customer retention and more effective marketing [19].

A service and performance measurement, established for each stage of the supply chain, is the third component. Performance measurements, as well as financial information, are needed to monitor SCM performances. Examples of key performance indicators are supplier reliability and supplier led-time to monitor the supply performance. Process reliability, changeover time, and schedule attainment can be measured to monitor the production. Perfect order completion, order fill rate, on-time delivery, and replenishment lead time are used to measure the delivery performance [1].

The fourth component is marked improvement. SCM is a system which adds value to customers, suppliers and whole channel members. Effective SCM requires partners to build and maintain close long-term relationships. This relationship ties firms to each other and tie their success to the supply chain as a whole. SCM helps to improve of the organizational learning and information sharing [20]. As global markets grow increasingly efficient, competition no longer takes place between individual businesses, but between entire value chains. Collaboration through intelligent e-business networks will provide the competitive edge that enables all the participants in a value chain to prevail and grow [19].

The supply chain improvements indicate that SCM has the potential improve a firm's competitiveness. Supply chain capability is as important to a company's overall strategy as overall product strategy. SCM encourages management of processes across departments. By linking supply chain objectives to company strategy, decisions can be made between competing demands on the supply chain. Improvements in performance are driven by externally-based targets rather than by internal department objectives [21].

\section{Importance of Supply Chain Management}

The traditional view of SCM is to leverage the supply chain to achieve the lowest initial purchase prices while assuring supply. Typical characteristics include: multiple partners, partner evaluations based on purchase price, cost-based information bases, arms-length negotiations, formal short-term contracts, and centralized purchasing. Operating under these conditions encourages fierce competition among suppliers, often requiring playing one supplier against the others, and uses rewards or punishment based on performance. The fundamental assumption in this environment is that trading partners are interchangeable and that they will take advantage if they become too important. In addition, there is a belief that maximum competition, under the discipline of a free market, promotes a healthy and vigorous supply base which is predicated on the "survival of the fittest" [3].

Why has managing the supply chain become an issue for the 1990's? In part, the answer lies in the fact that few companies continue to be vertically integrated. Companies have become more specialized and they search for suppliers who can provide low cost, quality materials rather than their own source of supply. It becomes critical for companies to manage the entire network of supply to optimize overall performance. These organizations have realized that whenever a company deals with another company that performs the next phase of the supply chain, both stand to benefit from the other's success [21].

A second reason partially stems from increased national competition. Customers have multiple sources from which to choose to satisfy demand; locating product throughout the distribution channel for maximum customer accessibility at a minimum cost becomes crucial. Previously, companies looked at solving the distribution problem through maintaining inventory at various locations throughout the chain. However, the dynamic nature of the marketplace makes holding inventory a risky and potentially unprofitable business. Customers' buying habits are constantly changing, and competitors are continually adding and deleting products. Demand changes make it almost a sure bet that the company will have the wrong inventory. The cost of holding any inventory also means most companies cannot provide a low cost product when funds are tied up in inventory [21].

A third reason for the shift in emphasis to the supply chain is due to a realization by most companies that maximizing performance of one department or function may lead to less than optimal performance for the whole company. Purchasing may negotiate a lower the price on a component and receive a favourable purchase price variance, but to cost to produce the finished product may go up due to inefficiencies in the plant. Companies must look across the entire supply chain to gauge the impact of decisions in any one area [21]

Managers now acknowledge that a firm's success is tied, in part, to the strength of its weakest supply chain partner. Only through close collaborative linkages through the entire supply chain, can one fully achieve the 
benefits of cost reduction and revenue enhancing behaviours [3].

\section{RESEARCH METHODOLOGY}

This research documents a study of the dimensions of supply chain management associated with business performance. In particular, the research objective is to examine empirically the development and support of a SCM and its successful implementation in Turkish Drug / Pharmaceuticals businesses in Thrace Region as evidenced by successful business performance, and to investigate variations in business performance which may be related to SCM. It should be noted that business performance is dependent on more variables than just SCM but the main aim of this research is to provide a general overview of how important a SCM is in the Turkish Drug / Pharmaceuticals industry and its relationship with the business performance. In particular, this study has three objectives:

\section{- To define SCM.}

- To determine the implementation of SCM in the Turkish Drug / Pharmaceuticals Industry.

- To empirically assess the influence of SCM on business performance and to determine the relative importance of the dimensions of SCM in the SCM business performance relationship.

\section{MATERIAL AND METHODS}

In order to explore the effects of SCM on business performance, a two phase research design was adopted and conducted. First an exploratory phase was conducted in order to gain a clearer understanding of the key issues. To achieve exploratory part, the in-depth interviews were conducted with the President of the Pharmaceuticals Industry. Also some of the managers of Pharmaceutical Warehouses were interviewed. Second, a descriptive study was found most appropriate for this research and this was conducted by employing a survey using crosssectional data. The reason for focusing on this method is that descriptive studies rest on specific hypothesis, and they are often concerned with the frequency of occurrence or association between two or more variables [22]. They are used when the research is intended to describe the characteristics of groups or to make prediction on a relationship between variables [23]. The intention of using survey research was to describe and explain statistically the variability of certain features of the relationship between SCM and business performance in the Turkish Pharmaceuticals Industry. Lee et al. [1] SCM construct was used to test the hypothesis.

\section{Definition of the Population and Sampling}

The sample for both stages was drawn from a listing of the member companies of the Turkish Pharmaceuticals Association. This listing by the Association is complete and accurate because of the control which obligates businesses to register all their business actions. There were 74 pharmaceutical companies, 10 pharmaceutical warehouses and, 3609 retailer pharmacies (total 3693 company) in the list which was recorded by the Association. Then a systematic sampling method was chosen for selection of a representative sample out of the population. A total of 370 companies were systematically selected from 3693 registered companies.

Design of the Research Instrument: The questionnaire was originally designed in English. But since this specific research was being undertaken in Turkey, it was translated into Turkish. Before the questionnaire was sent out, it was pre-tested and refined with a number of managers and academics who are known personally by the researcher, thus ensuring that the questions were relevant and phrased in a meaningful manner.

\section{Reliability}

The reliability of the SCM scale is .811 . Therefore the scale items demonstrates reliability by satisfying the statistical criteria, and this evidence of reliability clearly indicates that the items included in the scale that measure the four components of SCM are all related to a common construct, namely the degree of SCM.

\section{Content Validity}

There are two approaches for assessing content validity; face validity and sampling validity. Before the questionnaire was dispatched, it was pre-tested and refined with a number of managers and academics, thus ensuring that the questions were relevant and phrased in a meaningful manner. On the basis of their comments, some modifications were necessary to the SCM measures according to characteristics of the Turkish Drug / Pharmaceuticals industry. This provided face validity. The second approach sampling validity, concerns whether the content of the instrument adequately represent the property being measured. Lee et al.'s [1] questionnaire was based upon scientific methods, therefore the scale can be considered to posses sampling validity.

The questionnaire was based on the measures of Lee et al. [1] SCM construct because their instrument had been developed, tested and refined and yielded reliable results. 
- Supply Chain Management Scale: This part of the questionnaire comprised four dimensions, namely technology, utility expectations, performance and improvement. The measures included 6 items to capture technology, 7 for utility expectations, 7 for performance, and 5 for improvement. There were 25 items in total. Items were scored on a 5 point Likert scale, ranging from 'not at all' to 'very high'.

- Performance Scale: Performance can be measured by using objective or subjective measures. Previous studies that have used both the objective and subjective measures found a strong correlation between the two. In this research, subjective measures were applied. Relationships with customers, relationships with suppliers, key suppliers, strategy usage, general performance, company activity (sales volume), company activity (market share), comparing with competitors (sales volume), comparing with competitors (market share) were the subjective measures of the business performance.

\section{Data Collection}

Data collection was achieved through mail questionnaires. After the process of data checking, a total of 106 useable surveys remained for the analysis. Due to missing data on some of the key constructs 25 questionnaires were deemed unusable, yielding 106 usable questionnaires out of 131 replies, a response rate of $28,64 \%(106 / 370)$. A non-response analysis was conducted by comparing responses from the original sample and they did not differ significantly. Therefore, the sample can be considered reasonably representative. Results were analyzed using SPSS statistical analysis computer package.

\section{RESULTS AND DISCUSSION}

The objective of this research was to explore the nature of SCM practices by using empirical data from a sample of businesses to examine some hypotheses regarding supply chain management practices in Turkish Drug / Pharmaceuticals industry. This objective was fulfilled by reliably and validly measuring the key constructs of SCM and finding statistically significant relationships between dependent and independent variables.

There are four assumptions of multiple regression analysis: linearity of the variate, constant variance of error terms, independence of error terms, normal distribution of error terms. All of these assumptions are met. After assessing assumptions and model fit, multicollinearity is assessed. Condition index values exceeding 15-30 signal a multicollinearity problem. No condition index is greater than 15, thus, there is no sign of multicollinearity. Very small tolerance values (and thus large VIF values because $\mathrm{VIF}=1 /$ tolerance) denote high collinearity. A common cutoff threshold is a tolerance value of .10, which corresponds to a VIF value above 10 [24]. Tolerance values are very high which needs to be higher than .10 . Likewise, the VIF values are much less than 10. Thus there is no problem of multicollinearity.

SCM scale was factor analyzed via principal component factor analysis with varimax rotation, and without any restriction on the number of factors to be extracted. The analysis revealed the factor structure proposed by Lee et al. [1]. After factor analysis, only one variable for each of the dimension (technology, utility expectations, performance and improvement) was generated and these variables were entered into the regression model as independent variables.

The equation for the analysis is:

$$
Y=a+b_{1} X_{1}+b_{2} X_{2}+b_{3} X_{3}+b_{4} X_{4}+e
$$

Where:

$X$ 's are independent variables which influence the dependent variable

$$
\begin{aligned}
& \mathrm{X}_{1} \text { Technology } \\
& \mathrm{X}_{2} \text { Utility Expectations } \\
& \mathrm{X}_{3} \text { Performance } \\
& \mathrm{X}_{4} \text { Improvement }
\end{aligned}
$$

$a$ is the value of the constant and intercept derived from the analysis

b's are estimated regression coefficients associated with the independent variable

e is an error term which points to the fact that a proportion of the variance in the dependent variable

$\mathrm{Y}$ is unexplained by the regression equation which is estimated value of the dependent variable

\section{Research Results}

The multidimensional operationalisation of SCM allowed the testing of the relationship between the dimensions of SCM with dimensions of business performance. Multi regression analysis has been employed to assess the nature and extent of the collective relationship between the dimensions of SCM and the dimensions of business performance. So, this analysis will involve separate examination of the individual relationships between the identified dimensions of SCM and the identified dimensions of business performance. 
This is to determine the relative importance of the SCM dimensions with the business performance to find out which dimensions of supply chain management are most highly associated with business performance. It is also to find out whether each of the four dimensions of SCM contributes significantly to the prediction of each dimension of business performance.

Regression analysis found a significant effect of the level of SCM on dimensions of business performance as can be seen below (Table.1):

Relationships with customers $=0,032+0,393$ Utility Expectations $+0,269$ Improvement

Relationships with suppliers $=-0,004+0,530$ Utility Expectations

Key suppliers $=0,037+0,402$ Performance

Strategy Usage $=-0,036+0,391$ Improvement

General Performance $=3,597+0,335$ Improvement Improvement

Company Activity (Sales Volume) $=3,487+0,349$

Company Activity (Market Share) $=3,228+0,304$ Improvement

Comparing with Competitors (Sales Volume)= $3,335+0,403$ Improvement

Comparing with Competitors (Market Share)=

$3,229+0,259$ Improvement

Table.1. Summary of the Equations for all Dependent Variables

\begin{tabular}{|l|l|c|c|c|c|c|c|c|}
\hline Dependent Variables & $\begin{array}{l}\text { Supply Chain } \\
\text { Management } \\
\text { Components }\end{array}$ & $\mathbf{B}$ & $\mathbf{R}$ & $\mathbf{R}^{2}$ & $\mathbf{B e t a}$ & $\mathbf{t}$ & $\begin{array}{c}\text { Signifance } \\
\text { Level }\end{array}$ & $\begin{array}{c}\text { Standard } \\
\text { Error }\end{array}$ \\
\hline Relationships with Customers & $\begin{array}{l}\text { Utility Expectations } \\
\text { Improvement }\end{array}$ & $\begin{array}{l}0,393 \\
0,269\end{array}$ & 0,693 & 0,480 & 0,492 & 4,810 & 0,000 & 0,082 \\
0,292 & 2,852 & 0,006 \\
\hline Relationships with Suppliers & Utility Expectations & 0,530 & 0,542 & 0,294 & 0,542 & 5,364 & 0,000 & 0,099 \\
\hline Key Suppliers & Performance & 0,402 & 0,417 & 0,174 & 0,417 & 3,784 & 0,000 & 0,106 \\
\hline Strategy Usage & Improvement & 0,391 & 0,406 & 0,165 & 0,406 & 3,610 & 0,001 & 0,108 \\
\hline General Performance & Improvement & 0,335 & 0,432 & 0,187 & 0,432 & 3,980 & 0,000 & 0,084 \\
\hline $\begin{array}{l}\text { Company Activity (Sales } \\
\text { Volume) }\end{array}$ & Improvement & 0,349 & 0,399 & 0,159 & 0,399 & 3,590 & 0,001 & 0,097 \\
\hline $\begin{array}{l}\text { Company Activity } \\
\text { (Market Share) }\end{array}$ & Improvement & 0,304 & 0,327 & 0,107 & 0,327 & 2,828 & 0,006 & 0,107 \\
\hline $\begin{array}{l}\text { Comparing with Competitors } \\
\text { (Sales Volume) }\end{array}$ & Improvement & 0,403 & 0,356 & 0,126 & 0,356 & 3,090 & 0,003 & 0,130 \\
\hline $\begin{array}{l}\text { Comparing with Competitors } \\
\text { (Market Share) }\end{array}$ & Improvement & 0,259 & 0,251 & 0,063 & 0,251 & 2,111 & 0,039 & 0,123 \\
\hline
\end{tabular}

In brief, SCM activity implementation showed statistically significant relationships with customers in terms of utility expectations and improvement and with suppliers in terms of utility expectations. Also, SCM activity implementation is closely related with key suppliers' delivery performance according to the results which are shown above. This finding is consistent with the definitions of SCM [10] that the cooperation between chain members determines the SCM activity implementation level.

SCM activity implementation showed statistically significant with Strategy Usage in terms of improvement. Respondents managed the most partnership-like and longterm based relationships with their retailer customers and suppliers in terms of information and technology sharing and collaborative planning, forecasting and replenishment. This finding supports the observation [14] that close partnership is not only a prerequisite for the SCM, but also a benefit of it. SCM activity implementation showed statistically significant with General Performance, Company Activity (Sales Volume), Company Activity (Market Share), Comparing with Competitors (Sales Volume), Comparing with Competitors (Market Share) in terms of improvement. This means that a high level of SCM activity implementation is closely related with general performance, company activities as sales volume and market shares, comparing with competitors as sales volume and market shares. Over the long-term, the supply chain that forges "virtual firm" relationships in those situations where uncertainty is highest and where the cost of success (or failure) is greatest will prevail [3] 


\section{CONCLUSION}

Overall, this research has achieved its objectives and provided a better understanding of SCM and business performance concepts and possible relationships between these in the Turkish Drug / Pharmaceuticals industry. The findings have been empirically supported and this research has achieved a significant contribution to knowledge by providing an understanding of how the dimensions of SCM effects the dimensions of business performance. Shortly, according to the result of this paper, SCM activities are statistically significant at two dimensions which are improvement in customer relationships and utility expectations. Consequently, through the SCM activities, improvement is seen in customer relationships and the company has benefit as a result of this change. Moreover, at supplier relationships side, a statistically significant and positive result appears on utility expectation dimension. This means, as SCM activities turn supplier relationships into a long term and quasi partnership relationships, company has benefit.

\section{REFERENCES}

[1] Lee, Y. \& Kincade, D.H.. (2003). US Apparel Manufacturers' Company Characteristic Differences Based On SCM Activities. Journal of Fashion Marketing and Management, 7(1), 31-48.

[2] Spekman, R.; Salmond, D. \& Kamauff, J. (1994). At Last Procurement Becomes Strategic. Long Range Planning, 27(2), 76-84.

[3] Spekman, R.; Kamauff, J. \& Myhr, N. (1998). An Empirical Investigation into Supply Chain Management: A Perspective on Partnerships. Supply Chain Management, $3(2), 53-67$.

[4] Bommer, M.; O'Neil, B. \& Treat, S. (2001). Strategic Assessment of The Supply Chain Interface: A Beverage Industry Case Study. International Journal of Physical Distribution \& Logistics Management, 31(1), 11-25.

[5] Ritchie, B. \& Brindley, C. (2002). Re-assessing The Management of The Global Supply Chain. Integrated Manufacturing Systems, 13(2), 110-116.

[6] Supply Chain Management and Logistics Management Definitions.(http://www.cscmp.org/Website/AboutCSCMP/ Definitions/Definitions.asp). [19.07.06]

[7] Chen, I.J. \& Paulraj, A. (2004). Towards A Theory Of Supply Chain Management: The Constructs And Measurement. Journal of Operations Management, 22(2), 119-150.

[8] (http//www.clml.org). [05.09.05].
[9] Lummus, R.R.; Krumwlede, D.W. \& Vokurka, R.J. (2001). The Relationship of Logistics to Supply Chain Management: Developing A Common Industry Definition. Industrial Management and Data Systems, 1011(8), 426431.

[10] Mentzer, J.T.; Min, S. \& Zacharia, Z.G. (2000). The Nature of Interfirm Partnering In Supply Chain Management. Journal of Retailing, 76(4), 549-568.

[11] Chandra, C. \& Kumar, S. (2000). Supply Chain Management In Theory and Practise: A Passing Fad Or A Fundamental Change. Industrial Management \& Data Systems, 100(3), 100-114.

[12] Lambert, D.M.; Cooper, M.C. \& Pagh, J.D. (1998). Supply Chain Management: Implementation Issues and Research Opportunities. The International Journal of Logistics Management, 7(2), 1-19.

[13] Carter, J.R.; Ferrin, B.G. \& Carter, C.R. (1995). The Effect Of Less-Than-Truckload Rates On The Purchase Order Lot Size Decision. Transportation Journal, 34(3), 35-44.

[14] Ellram, L.M. \& Cooper, M.C. (1993). Characteristics of Supply Chain Management and The Implications For Purchasing And Logistics Strategy. International Journal of Logistics Management, 4(2), 13-24.

[15] Turner, J.R. (1993). Integrated Supply Chain Management: What's Wrong With This Picture? Industrial Engineering, 25(12), 52-55.

[16] Christopher, M. (1992). Logistics: The Strategic Issues. London: Chapman \& Hall.

[17] Towil, D.R.; Naim, M.M. \& Wikner, J. (1992). Industrial Dynamics Simulation Models In The Design Of Supply Chains. Industrial Journal of Physical Distribution, 22(5), 3-13.

[18] Cavinato, J.L. (1992). A Total Cost / Value Model For Supply Chain Competitiveness. Journal of Business Logistics, 13(2), 285-301.

[19] Horvath, L. (2001). Collaboration: The Key to Value Creation in Supply Chain Management. Supply Chain Management: An International Journal, 6(5), 205-207.

[20] Min, S. \& Mentzer, J.T. (2000). The Role of Marketing in Supply Chain Management. International Journal of Physical Distribution \& Logistics Management, 30(9), 765 787.

[21] Lummus, R.R. \& Vokurka, R.J. (1999). Defining Supply Chain Management: A Historical Perspective and Practical Guidelines. Industrial Management and Data Systems, 99(1), 11-17. 
[22] Harris, L.J. (1997). A Study of Organizational Culture Factors Associated with Market Orientation. Unpublished Ph.D Thesis, Cardiff Business School, University of Wales.

[23] Churchill, G.A. (1983). Marketing Research: Methodological Foundations. Third Edition. New York: The Dryden Press.

[24] Hair, J.F.Jr.; Anderson, R.E.; Tatham, R.L. \& Black, W.C. (1998). Multivariate Data Analysis. Fifth Ed. New York: Prentice Hall.
Ayşe AKYOL (ayseakyol@trakya.edu.tr) graduated from Istanbul Vefa High School in 1986, Dokuz Eylul University, Faculty of Economics and Administrative Sciences in 1991 (BA). She has got graduate degrees from Istanbul University, Faculty of Business (MA in Personel Management) in 1996, University of Portsmouth, Business School (MSc in Research \& Consultancy and $\mathrm{Ph} . \mathrm{D}$ in Marketing) in 2000, University of South Florida (post doctoral research) in 2005. She is still working at Trakya University as Associate Professor where she teaches Principles of Marketing, Marketing Management, International Marketing, Contemporary Issues in Marketing, Research Methodology. Her specific research fields are Marketing Theory, International Marketing and Wine Marketing.

Güzin CIRAVOĞLU (gciravoglu@yahoo.com) graduated from Çorlu High School in 1976 and Eskişehir Academy of Economics and Commercial Sciences (EITIA) Industrial Sciences Faculty Chemical Engineering Section in 1980. She got her MBA Degree from İstanbul University, Managerial Economics Institute and MA Degree in Business Administration from Trakya University Faculty of Economics and Administrative Sciences (IIBF) in 2006. She works as a contract lecturer at both Kirklareli Universiy Babaeski Vocational College and Trakya University Havsa Vocational College where she teaches management and organization, crisis management and entrepreneurship and small business management. 